\title{
熱応力駆動型引張り試験による純チタン切欠き薄膜の引張り*
}

\author{
多田直 哉*1, 清 水一 郎*1 \\ 上森一 真*2, 多田寛 之*3
}

\section{Tensile Test of Notched Thin Film of Pure Titanium Actuated by Thermal Stress}

\author{
Naoya TADA*4, Ichiro SHIMIZU, \\ Kazumasa UEMORI and Hiroyuki TADA \\ ${ }^{* 4}$ Graduate School of Natural Science and Technology, Okayama University, \\ 3-1-1 Tsushimanaka, Okayama-shi, Okayama, 700-8530 Japan
}

\begin{abstract}
Tensile tests of notched thin film of pure titanium were carried out on the stage of a digital microscope. Tensile load was generated by the thermal expansion of a pair of polycarbonate loading plates by which the specimen was sandwiched. Since the thermal expansion coefficient of polycarbonate is much larger than that of pure titanium, the specimen was elongated with an increase in the temperature and successfully fractured at the end of the tensile test. The plastic deformation of the notched part of specimen was observed during the test and the stress and strain were evaluated. The obtained stress-strain curve situated between two curves by a commercial tensile testing machine at the room temperature and at $363 \mathrm{~K}$, which approximately corresponds to the maximum temperature of the thermal stress-actuated tensile test. As the mechanism of the proposed tensile test is simple, it is expected to be applicable to much smaller specimens in the future.
\end{abstract}

Key Words : Thermal Stress, Experimental Mechanics, Tensile Properties, Thin Film, Pure Titanium, Polycarbonate, Loading Plate, Thermal Expansion Coefficient

\section{1. 緒 言}

近年, 半導体デバイスや微小電気機械システム (micro-electro-mechanical systems; MEMS) を応用し た各種センサ一等の強度や信頼性評価のため, 微小寸 法材料に関する力学的試験が注目されている. 例えば, Read らは, 非接触渦電流変位センサーとピエゾ・ア クチュエータを具備する試験機を作製するとともに半 導体製造プロセスで用いられているフォトリソグラフ ィーとエッチングの技術を用いて Ti-Al-Ti や Ti-Cu-Ti の薄膜試験片を作製し，引張り試験を実施している (1),(2).また，最近では，3軸のマニピュレータを用い て微小なタングステン・フックを操作し, 試験片の一 端に設けた微小穴にそのフックを引っかけた後，穴に 引張り側の変位を与えることにより, 純アルミニウム

* 原稿受付 2007 年 7 月 2 日.

*1 正員, 岡山大学大学院自然科学研究科(- 700-8530 岡山市 津島中 3-1-1).

*2 学生員, 岡山大学大学院自然科学研究科.

*3 ダイキン工業 (株) (画 530-8323 大阪市北区中崎西 2-4-12).

E-mail : tada@mech.okayama-u.ac.jp
やポリイミド，純銅に関して引張り試験を実施してい る ${ }^{(3)}$. Soboyejo らも, 厚さ $70 \mu \mathrm{m}$ から $270 \mu \mathrm{m}$ の純二 ッケル薄膜試験片を作製し，引張りおよび疲労試験を 実施するとともに，試験後の破面観察を通して疲労破 壊のメカニズムについて検討している(4),(5). さらに, Haque らは，微細加工技術を用いて，厚さが $30 \mathrm{~nm}$ ら $50 \mathrm{~nm}$ の純アルミニウム微小試験片の周辺に, 単 結晶シリコン製のカセンサー, 試験片を正確に支持す るための梁, ひずみ測定のための突起マーカーを形成 し，引張りおよび片持ち梁試験を実施している(6)(7). 他にも静電チャックを用いて試験片をより精密につか む装置を具備した試験装置の開発例(8),(9)や薄膜内の応 力を $\mathrm{X}$ 線で評価した例(10)等, 最近では, 微小寸法材 料に関する報告例 ${ }^{(11)(17)}$ は少なくない。

一般に, 微小寸法材料の力学的試験を実施する際 の問題点は大きく次の三つに分類される ${ }^{(18)}$.

1)試験片の作製および取扱い

2) 荷重負荷時の摩擦

3)ひずみ測定 
これらの問題点を克服するため, いずれの研究例にお いても半導体製造プロセスやピエゾ・アクチュエータ, マニピュレータを始め, 精密機器が多用されている.

一方, 高分子材料等の薄膜に作用する残留応力を 評価する興味深い万法として, 評価対象となる薄膜の 一部に予め微小なパターン（例えば， $\mathrm{T}$ 字型のくり抜 き残留部）を形成しておき，そのパターン直下の基材 を除去し，その除去前後におけるパターンの寸法，形 状の変化を力学的に解析することにより, 薄膜の残留 応力を評価する方法が提案されている(19). これは,

Loading plate

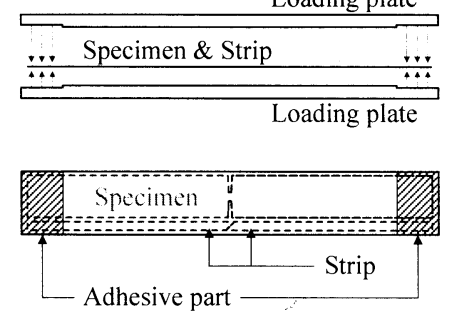

(a) Test structure.

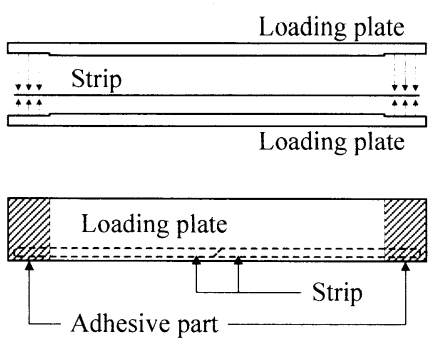

(b) Dummy structure.

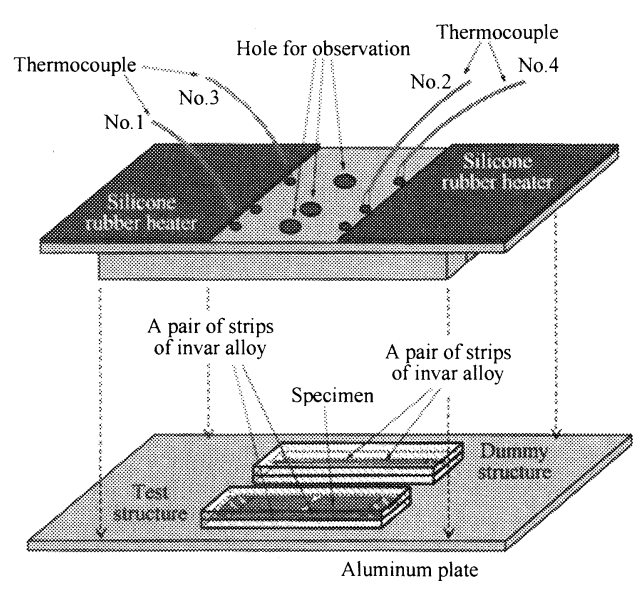

(c) All devices.

Fig.l Experimental devices on the stage of a digital microscope.
薄膜周辺の力学的境界条件を変化させることにより薄 膜に変形を与え，その変形から薄膜に作用していた応 力を評価する方法である。この方法では，薄膜に与え る力学的負荷条件を自由に変えることは難しいが，実 際の製品に近い形で作製した薄膜の力学的状態を把握 できるという特徴を有する.

以上の状況を鑑み, 筆者らも, 純チタン薄膜試験 片を用いてその力学的特性や塑性変形について検討す るため, 高分子材料の中でも比較的高い耐熱性，透明 性を有するポリカーボネート板材の熱膨張を用いて金 属薄膜の引張り試験を実施する熱忘力駆動型引張り試 験を提案している．前報(20)では，それが原理的に可 能であり, 熱膨張のみで薄膜の破断が可能であること を実験的に確認した. 本研究では, 試験方法に改良を 加えるとともに, 試験結果の 1 つとして得られる応力 一ひずみ線図に関して, 他の試験装置を用いて得た結 果と比較検討した. 現状では, ポリカーボネート板材 と金属薄膜を接着することにより試験を実施している が, 将来的には, 前述の薄膜の残留応力を評価する研 究例と同様に，実製品の一部分を引張り試験用に微細 加工し，その基材に熱負荷を与えることにより実製品 上の薄膜の力学的特性を得ることを目標としている.

\section{2. 試 験 方 法}

\section{$2 \cdot 1$ 熱応力駆動型引張り試験の原理}

本研究で提案する引張り試験の原理について以下に 説明する. 図 1 (a)に示すように, 評価対象である切 欠き薄膜試験片を，それより相対的に線膨張係数の大 きな材料で作製した 2 枚の負荷板（loading plate）で 挟むとともに, 試験片の両端と負荷板の内表面を接着 する. 本研究では, この構造体を試験構造体（test structure）と呼ぶことにする. この構造体を一様に加 熱すると, 薄膜試験片の両端は, 線膨張係数の大きな 負荷板の熱膨張により外側に引っ張られ, 試験片には 引張り荷重が作用する。 さらに, 本研究では, 図 1 (b)に示負荷板間に試験片を拥入しない構造体であ るダミー構造体 (dummy structure) を図 1 (c)に示す ように先の試験構造体に隣接して配置する. 詳細は, 後述するが, 両構造体における負荷板の変位差を測定 することにより, 引張り試験中に試験片に作用してい る引張り荷重を評価することができる，両構造体の負 荷板の間に挿入しているインバー合金製ストリップ （短冊）は, 負荷板の変位測定に用いる. 現在まで, 薄膜や細線の力学的試験用に静電力や磁力, 熱, 形状 記憶合金，流体，圧電素子等を用いた様々なアクチュ エータが提案されている(21)が，本研究で採用する熱 
応力駆動型引張り試験は, その中の熱アクチュエータ に分類される.

\section{$2 \cdot 2$ 試験片および負荷板}

試験片の寸法および形状を図 2 に示す。試験片には, 厚さ $0.04 \mathrm{~mm}$ の工業用純チタン（ヤング率 $105.8 \mathrm{GPa}$, 線膨張係数 $\left.8.6 \times 10^{-6} \mathrm{~K}^{-1}{ }^{(22)}\right)$ 薄膜を用い, ワイヤーカ ット放電加工で全長 $97 \mathrm{~mm}$, 幅 $10 \mathrm{~mm}$ の切欠き付試 験片に加工した. 中央部に設けた切欠き底の長さ $l_{S}$ は, $0.4 \mathrm{~mm}$ と $0.7 \mathrm{~mm}$ の二種類である. 本論文では，前者 を試験片 A，後者を試験片 B と呼ぶことにする。い ずれの試験片においても, 加工後, 残留応力除去のた めに温度 $1073 \mathrm{~K}$ ，保持時間 $1 \mathrm{~h}$ の条件で真空焼鈍を施 すとともに，酸化膜除去と試験片表面の平滑化を目的 として，メタノール，2-ブトキシエタノール，過塩素 酸（70\%）を 10:6:1 の体積比で混合した溶液で電解研 磨を行った。また，結晶粒の識別を容易にするため， 蒸留水, 硝酸, フッ化水素酸を 20:1:2 の体積比で混 合した溶液で化学腐食を行った．平均結晶粒径は，約 $38 \mu \mathrm{m}$ である.

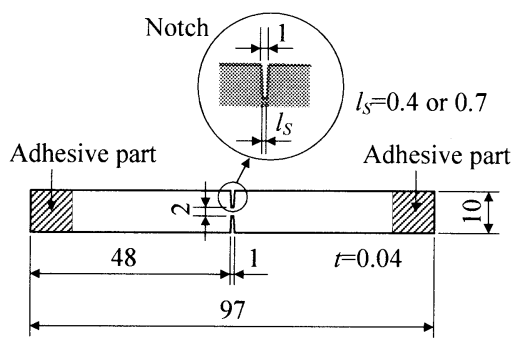

Fig.2 Shape and size of notched thin film specimen of pure titanium (in $\mathrm{mm}$ ).

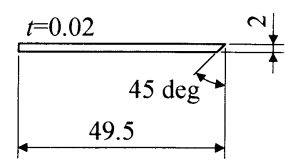

Fig.3 Shape and size of strip of invar alloy for displacement measurement (in $\mathrm{mm}$ ).

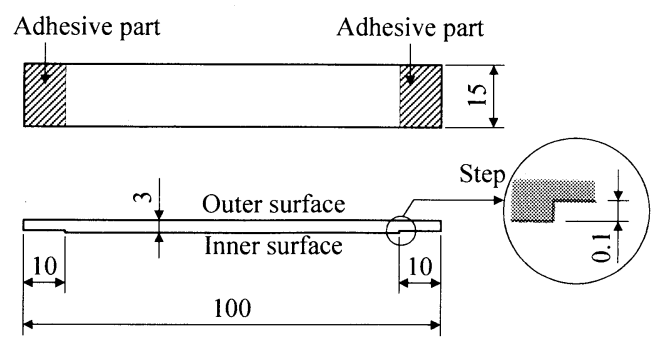

Fig.4 Shape and size of loading plate of polycarbonate (in $\mathrm{mm}$ ).
Table 1 Young's modulus of polycarbonate

\begin{tabular}{c|c}
\hline Temperature $T[\mathrm{~K}]$ & Young's modulus $E_{L}[\mathrm{GPa}]$ \\
\hline R.T. & 2.21 \\
\hline 323 & 2.06 \\
\hline 363 & 1.84 \\
\hline
\end{tabular}

変位計測のために負荷板間に挿入，接着した 1 対の 対向するインバー合金製ストリップ（短冊）の寸法お よび形状を図 3 に示す．ストリップは，厚さ $0.02 \mathrm{~mm}$ のインバー合金製薄板からカッターナイフで切り出し た. 斜めに加工したストリップ先端部分には微小硬さ 試験機（（株）アカシ, MVK-HO）により圧痕を設け， 変位を測定する際の目印とした。

負荷板の寸法および形状を図 4 に示す．負荷板には 厚さ $3 \mathrm{~mm}$ のポリカーボネート（線膨張係数 $65 \times 10^{-6}$ $\left.\mathrm{K}^{-1}{ }^{(23)}\right)$ 平板を用いた。 ポリカーボネートは，試験材 料の純チタンと比較して線膨張係数が高く，かつ，高 分子材料の中では耐熱性も高い.また，透明性を有す るため, 観察のための光源も通しやすく, 中に挟まれ た試験片の観察も比較的容易である. ポリカーボネー トの平板を長さ $100 \mathrm{~mm}$, 幅 $15 \mathrm{~mm}$ に機械加工し, そ の中央付近に，試験片切欠き部を観察するための直径 $2 \mathrm{~mm}$ の穴とインバー合金製ストリップ先端を観察す るための直径 $1 \mathrm{~mm}$ の穴を設けた. さらに, 試験片と 接着する箇所である長さ $10 \mathrm{~mm}$ の両端部は，接着剂 厚さの影響を極力少なくするため, 高さ $0.1 \mathrm{~mm}$ の段 差を設けた. 本研究では, 試験片に作用している荷重 を算出する際にポリカーボネートのヤング率およびそ の温度依存性に関するデータが必要であるが，この值 は別途他の試験機を用いて室温, $323 \mathrm{~K}, 363 \mathrm{~K}$ の 3 温度レベルで引張り試験を実施することにより, 予め 取得した。その結果を表 1 に示す.

試験構造体およびダミ一構造体における試験片とス トリップの負荷板内表面への接着剤には，使用可能温 度範囲が $218 \mathrm{~K}$ から $473 \mathrm{~K}$ と比較的高い温度まで使用 可能なエポキシ系接着剂（共和電業（株）, EP34B）を用い，接着領域は，負荷板の両端に位置する 大きさ $10 \mathrm{~mm} \times 15 \mathrm{~mm}$ の段差部とした.

\section{$2 \cdot 3$ 加熱方法および温度測定}

本試験では両構造体を加熱し, 試験片と負荷板の 線膨張係数の差により, 試験片に引張り応力を発生さ せる. したがって, 加熱条件が引張り負荷条件に相当 する.

図 1 に示すように, 各構造体の加熱にはシリコー ンラバー・ヒーターを用いた，構造体中の温度をでき 
るだけ均一に保つため, 両構造体を熱伝導の良い厚さ $3 \mathrm{~mm}$ の純アルミニウム製のカバーで覆い, ヒーター は，その外面に設置した。また，アルミニウム製カバ 一には，温度測定のための熱電対を挿入するための穴 に加えて, 試験構造体内の試験片表面とインバー合金 製ストリップおよびダミ一構造体内のインバー合金製 ストリップを観察するための穴を設けた。

各構造体の加熱は，段階的に行った．各保持温度 では, 試験片中央の切欠き位置から長手方向に 18.5 $\mathrm{mm}$ 離れた負荷板上の 4 箇所（図 1 (c) 中の No.1 から No.4）で測定した温度がほぼ定常状態になってから試 験片切欠き部の観察およびストリップ間距離の測定を 実施した。 なお，保持温度は，室温から室温+5 K ま では, $1 \mathrm{~K}$ 刻みで, その後は $5 \mathrm{~K}$ 刻みで増加させた。 本試験を開始する前に, 試験片やストリップと負荷板 内面間に生じる摩擦の影響を軽減するため, 室温から 温度を $5 \mathrm{~K}$ 上昇させ, 再び室温に戻すという操作を 3 回繰返した。 なお，温度測定には，アルメル・クロメ ル熱電対を用いた.

\section{$2 \cdot 4$ 試験荷重の測定方法}

試験構造体では，試験片に作用している引張り荷 重と負荷板の圧縮荷重が互いに釣合い状態にある。し たがって，試験中に負荷板のひずみが測定でき，かつ， 負荷板に使用しているポリカーボネートのヤング率が 既知であれば，負荷板に作用する圧縮荷重，すなわち 試験片に作用する引張り荷重を求めることができる. 本研究では, 以下の手順で試験片に作用する荷重を評 価した。

1) 各保持温度 $(i$ 回目) において, 試験構造体お よびダミー構造体内に挿入したインバー合金製ストリ ップ間の距離を測定し，前回測定時 $(i-1$ 回目) との 差から各構造体における負荷板の変位 $\left.\lambda_{T}\right|_{i},\left.\lambda_{D}\right|_{i}$ を求 める.

2) 式(1)および(2)で示すように, 変位 $\left.\lambda_{T}\right|_{i},\left.\quad \lambda_{D}\right|_{i}$ をストリップの有効長さ $\left.l_{T}\right|_{i},\left.l_{D}\right|_{i}$ で除することによ $\eta$, 保持温度間のひずみ増分 $\left.\Delta \varepsilon_{T}\right|_{i},\left.\Delta \varepsilon_{D}\right|_{i}$ ，を求める. なお, この有効長さとは, 通常の引張り試験において ゲージ長さに相当するものであり, 本研究では, 負荷 板の全長 $(100 \mathrm{~mm})$ から両端の接着長さ $10 \mathrm{~mm}$ の半 分ずつを引いた長さ $(=100-2 \times 5=90 \mathrm{~mm})$, すなわち, 両接着領域の中心間距離を実際に測定し, 初期值とし た. 通常の引張り試験では,この負荷板の有効長さ （ゲージ長さ）を接着部の内側間距離である $80 \mathrm{~mm}$ とするが, 本研究では, 負荷板のヤング率が試験片と 比較して小さいため, 両接着部の中心点が負荷板の変 形を代表する点であると考え, 上述の有効長さを採用
した.さらに, 引張り試験の進行とともに各保持温度 で得られた変位を，式(3)に示すようにそのときの有 効長さに加え, 有効長さを更新しながらひずみ増分を 評価した.

$$
\begin{aligned}
& \left.\Delta \varepsilon_{T}\right|_{i}=\frac{\left.\lambda_{T}\right|_{i}}{\left.l_{T}\right|_{i}} \\
& \left.\Delta \varepsilon_{D}\right|_{i}=\frac{\left.\lambda_{D}\right|_{i}}{\left.l_{D}\right|_{i}} \\
& \left.l_{T}\right|_{i}=\left.l_{T}\right|_{i-1}+\left.\lambda_{T}\right|_{i-1} \\
& \left.l_{D}\right|_{i}=\left.l_{D}\right|_{i-1}+\left.\lambda_{D}\right|_{i-1}
\end{aligned}
$$

3）試験構造体を構成する負荷板のひずみ増分は, 熱膨張によるものと試験片から受ける引張り荷重に対 応する力学的なひずみとの和になる. 一方, ダミ一構 造体中の負荷板のひずみ増分は, 負荷板の純粋な熱膨 張ひずみからなる。したがって，それらを差し引き， さらに負荷板 2 枚分の断面積 $2 \times A_{L}$ とその温度におけ る負荷板のヤング率 $E_{L}$ を乗ずることにより, 負荷板 に作用している圧縮荷重, すなわち, 試験片に作用し ている引張り荷重 $W_{i}$ が次式より求められる.

$$
W_{i}=2 \times A_{L} \times E_{L} \times \sum_{i}\left(\left.\Delta \varepsilon_{D}\right|_{i}-\left.\Delta \varepsilon_{T}\right|_{i}\right)
$$

上式中のミは，各保持温度で算出されるひずみ増分を 累積することを意味する，負荷板のヤング率 $E_{L}$ は， 先述の表 1 に示したデ一タを線形補間した值を採用し, また，負荷板の断面積 $A_{L}$ は，試験片およびストリッ プの表面を観察するために設けた穴の影響を無視して 算出した。後出の切欠き部応力 $\sigma_{N}$ は，以上の方法に より求めた $W_{i}$ を試験開始前における切久き部の断面 積で除すことにより求めた。

\section{5 デジタル画像相関法によるストリップ先端間 距離の測定}

デジタル画像相関法（Digital Image Correlation Method） ${ }^{(24)}$ は，取得したデジタル画像に関してパタ ーン・マッチングを行い，高精度に変位等を解析する 方法として知られている. 本研究では, この手法をイ ンバー合金製ストリップ間の距離評価に用いた。具体 的には，注目領域（Region of Interest; ROI）をストリ ップ先端付近に導入した大きさ約 $30 \mu \mathrm{m}$ のビッカー ス圧痕とし，各保持温度において取得した 1 画素単位 のビッカース圧痕周辺の画像を二次元線形補間し $1 / 10$ 画素を単位とするより細かな画像に変換した。 その後, 各回の保持温度で取得した変換画像に対して 
相関係数を基準として同一領域を探索，決定した。本 研究では，取得した画像の 1 画素が $0.492 \mu \mathrm{m}$ となる ため, $1 / 10$ 画素が $0.0492 \mu \mathrm{m}$, 前述の負荷板の有効長 さの初期值が約 $90 \mathrm{~mm}$ であるため, 負荷板の最小ひ ずみが約 $5.5 \times 10^{-7}$ ， それに負荷板のヤング率（約 2 $\mathrm{GPa})$ と断面積 $(2 \times 15 \mathrm{~mm} \times 3 \mathrm{~mm})$ を乗じた最小荷重 が約 $0.1 \mathrm{~N}$ となる.したがって，この值から切欠き部 で評価しうる最小応力増分值を求めると約 $1.25 \mathrm{MPa}$ となる。

\section{$2 \cdot 6$ 切欠き底中心部におけるひずみの測定方法}

本研究では試験片切欠き部のひずみを，ほぼ切欠 き中央部に位置する結晶粒間の長手方向の距離変化か ら求めた．具体的には，試験開始前に，比較的識別が 容易で試験片長手方向の距離がおよそ $350 \mu \mathrm{m}$ である
結晶粒対を 3 組選んでおき, 各保持温度 ( $i$ 回目) に おいてそれらの試験片長手方向の距離 $\left.l_{g 1}\right|_{i}, l_{g 2}\left|i, l_{g 3}\right|_{i}$ を顕微鏡画像から測定するとともに，それらの平均值 $\left.l_{g}\right|_{i}$ を式(6)より求める. その平均距離を前回の保持温 度時に取得した值と比較し，その相対的な増加量から 式 (7) を用いてひずみ増分 $\Delta \varepsilon_{N i}$ を求める。実際のひず み $\varepsilon_{N}$ は，各温度保持時におけるひずみ増分を累積し て式(8)より求めた.

$$
\begin{aligned}
& \left.l_{g}\right|_{i}=\frac{\left.l_{g 1}\right|_{i}+\left.l_{g 2}\right|_{i}+\left.l_{g 3}\right|_{i}}{3} \\
& \left.\Delta \varepsilon_{N}\right|_{i}=\frac{\left.l_{g}\right|_{i}-\left.l_{g}\right|_{i-1}}{\left.l_{g}\right|_{i-1}}
\end{aligned}
$$



(a) Specimen A.

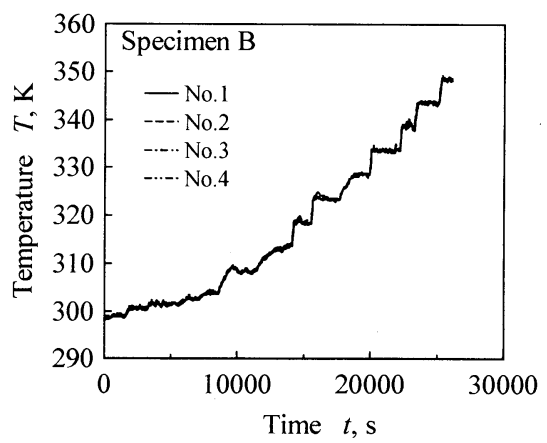

(b) Specimen B.

Fig.5 Change in temperature during tensile test.
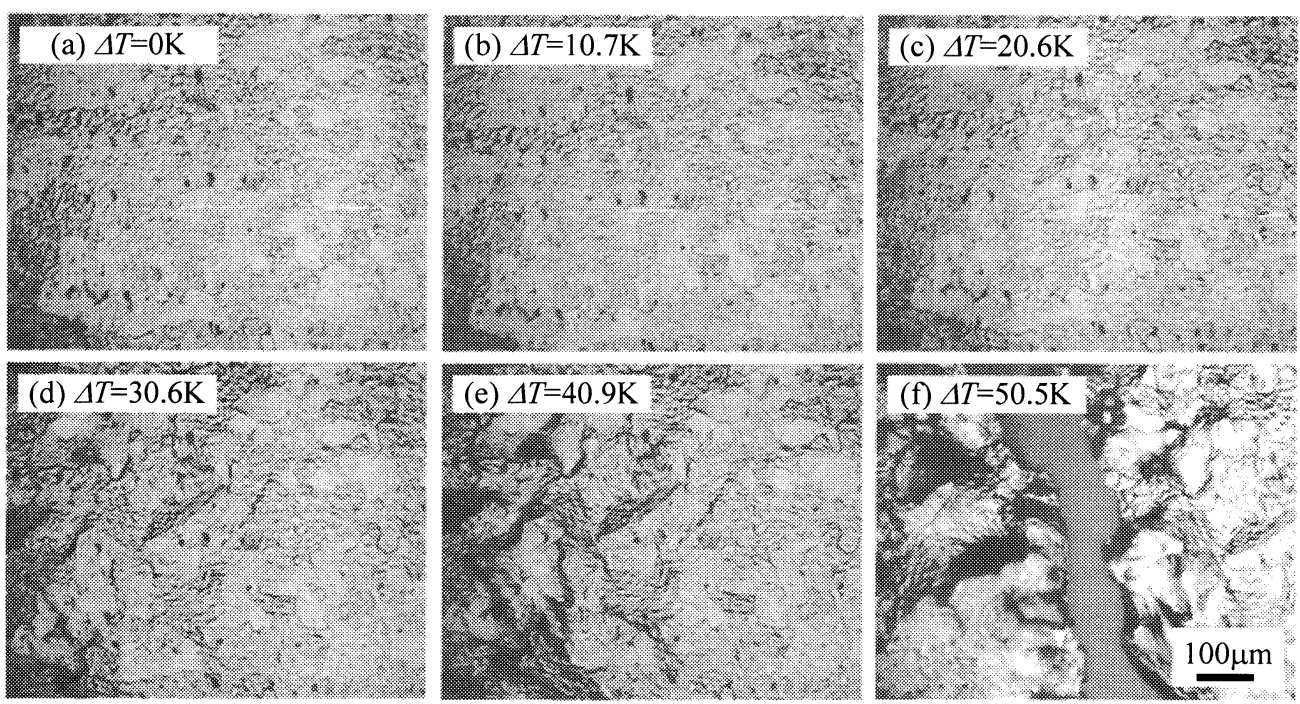

Fig.6 Specimen surface at the center of notched part in specimen B. 


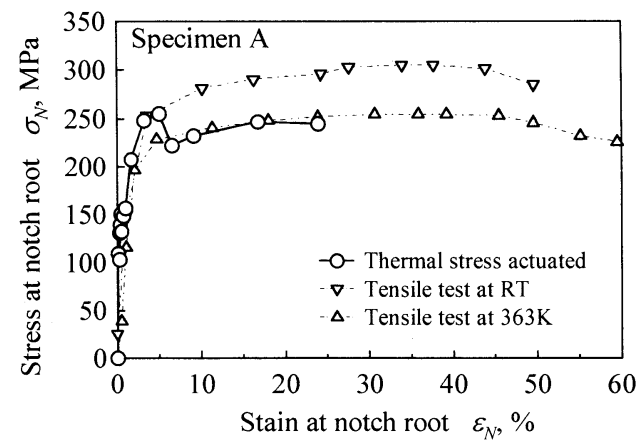

(a) Specimen A.

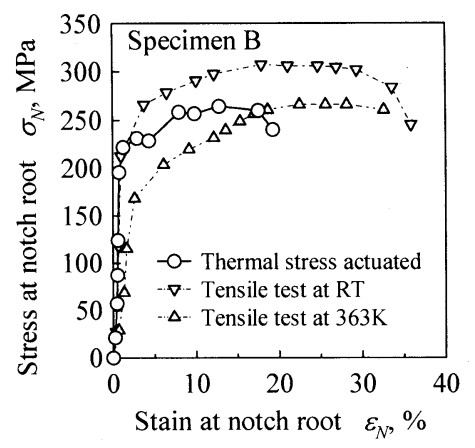

(b) Specimen B.

Fig.7 Stress-strain relationship at the center of notched part.

$$
\varepsilon_{N}=\left.\sum_{i} \Delta \varepsilon_{N}\right|_{i}
$$

\section{3. 実験結果と考察}

\section{1 両構造体の温度変化}

引張り試験中の温度変化を図 5 に示す，各保持温 度にお゙いて温度調整に微妙な違いがあり, また, 観察 に要した時間にも若干のばらつきがあったため, 各保 持温度における温度の経時変化に違いが見られるが, 試験構造体とダミ一構造体はほぼ同じ温度であった。 測定箇所間の最大温度差は $0.5 \mathrm{~K}$, 各保持温度におけ る温度変動幅（=| 最大温度一最小温度 $\mid$ ) は最大で $0.7 \mathrm{~K}$ であった. なお, 設定温度に達した後は, 温度 変動がほとんどなく, 最大でも $\pm 0.1 \mathrm{~K}$ であった。な お, 平均的な昇温速度は, 試験片 $\mathrm{A}$ において約 $1.55 \times 10^{-3} \mathrm{~K} / \mathrm{s}$, 試験片 B では約 $1.91 \times 10^{-3} \mathrm{~K} / \mathrm{s}$ であった.

\section{2 試験片切欠き部の様子}

引張り試験中に得られた試験片 $\mathrm{B}$ の切欠き部中心 付近の様子を図 6 に示す. 試験構造体の温度上昇に伴 い, 試験片に引張り荷重が生じ, 表面が次第にあれる とともに起伏が激しくなり, 最終的に破断に至る様子 がうかがえる. 試験片 A では, 試験構造体の温度が $297.1 \mathrm{~K}$ のときに試験を開始し, 温度上昇幅 $\Delta T$ が 57.6 Kのときに, また, 試験片 B では, 温度 $298.4 \mathrm{~K}$ で試 験を開始し, 温度上昇幅 $\Delta T$ が $50.5 \mathrm{~K}$ のときに試験片 が破断した. なお，両試験片間で試験片表面の様相に は大きな違いが見られず，いずれの試験片においても 寿命後期において切欠き底の角部からき裂が入り, そ れが成長，合体することで破断した。

\section{$3 \cdot 3$ 応カーひずみ線図}

図 7 に試験片切欠き部における応力ーひずみ関係 を示す. 試験片 A における最大応力は約 $255.2 \mathrm{MPa}$, 破断時のひずみは約 $23.8 \%$ であった。試験片 B では,
最大応力が約 $265.8 \mathrm{MPa}$ ，破断時のひずみは約 $19.2 \%$ であった，両試験片において最大応力と破断時のひず みは同程度であり, 切欠き底長さの影響は小さかった。 参考のため, 同図中には, 微小試験片用試験機（島津 製作所（株），MMT-100NB-10）を用いて，室温およ び熱応力駆動型引張り試験においてほぼ最高温度（= 試験片破断時の温度）に相当する $363 \mathrm{~K}$ の一定温度下 で実施した引張り試験の結果を示寸。この微小試験片 用試験機を用いた引張り試験では，熱応力駆動型引張 り試験で用いた試験片と同一の板幅，板厚および切久 きを有する長さ $97 \mathrm{~mm}$ の薄膜試験片を用いた. 試験 片の両端を小型のねじ締め式つかみ具により試験機に 固定し, 変位速度 $5 \times 10^{-4} \mathrm{~mm} / \mathrm{s}$ の条件で引張り負荷を 与えた. また, 加熱は, 熱忘力駆動型引張り試験と同 様にアルミニウムカバーを介してシリコーンラバー・ ヒーターにより行った，なお，切久き底のひずみは， 観察に使用した画像取得装置の関係上, 低倍率での観 察のみ可能であったため, 図8に示すように, 取得し た画像において切欠き底近傍における切久き形状を 3 本の直線で近似し，その切欠き底長さに相当する 2 線 分の長さ $l_{n 1}$ と $l_{n 2}$ の平均長さの変化から求めた.

さて, 図 7 において, 各試験より得られた応カレ



Fig.8 Approximated shape of notched part for strain evaluation. 
ベルを比較すると，熱応力駆動型引張り試験から得ら れた結果が室温および $363 \mathrm{~K}$ における結果の間に位置 し, 妥当な結果が得られていると考えられる. しかし ながら，破断ひずみに関しては比較的大きな差が見ら れる，その原因は，主として両試験における切久き底 のひずみ評価方法の違い，あるいは，その評価方法の 違いに起因するひずみ評価対象領域の違い（熱応力駆 動型引張り試験では切欠き底中心であるのに対し, 微 小試験片用試験機を用いた引張り試験では切欠き底全 体）に依存すると考えられる. 本研究で用いた試験片 の引張りでは，いずれの試験のおいても切欠き底周辺 が切欠き部の中心より大きな負荷軸方向のひずみを呈 する傾向が見られたが，図 7 に示した結果においても 同様の傾向が見られる.

\section{4. 結論}

本研究では, 高分子材料の高い線膨張係数を利用 して金属薄膜試験片の引張りを顕微鏡のステージ上で 実現する熱応力駆動型引張り試験を提案し, 純チタン 切久き薄膜の引張り試験を実施した. 得られた主な結 果を以下に示す.

（1）高い線膨張係数および而熱性，透明性を有する 2 枚のポリカーボネート製平板（負荷板）内に 純チタン切欠き薄膜試験片を挟み込み, 試験片 の両端部を負荷板内面に接着した構造体 (試験 構造体）を作製するとともに，その構造体を一 様に加熱することにより引張り試験を実施する 方法を提案した.

（2）試験片を含まない同一のポリカーボネート製構 造体（ダミ一構造体）を上述の試験構造体に隣 接して配置し, 試験構造体とこのダミー構造体 における負荷板のひずみを比較することにより 試験荷重を求める方法を提案した. 各構造体の ひずみは, 熱による膨張が小さいインバー合金 で作製した対向するストリップ対の先端間距離 に基づき評価した。

（3）提案した方法により, 純チタン切久き薄膜試験 片の引張り試験を実施し，試験片を破断するま での大きなひずみを与えることが可能であった.

（4）得られた切欠き部における応力一ひずみ関係を, 別途, 微小試験片用試験機を用いて求めた結果 と比較した. 応力値およびその変化に関しては, 妥当な結果が得られたが, 破断ひずみに関して は, ひずみの評価手法が異なるため, 比較的大 きな差があった.

\section{文献}

(1) Read, D.T. and Dally, J.W., A New Method for Measuring the Strength and Ductility of Thin Films, Journal of Materials Research, Vol.8, No.7 (1993-7), pp.1542-1549.

(2) Read, D.T., Tension-Tension Fatigue of Copper Thin Films, International Journal of Fatigue, Vol.20, No.3 (1998), pp.203-209.

(3) Cheng, Y-W., Read, D.T., McColskey, J.D. and Wright, J.E., A Tensile-Testing Technique for Micrometer-Sized Free-Standing Thin Films, Thin Solid Films, Vol.484, Issues 1-2 (2005-7), pp.426-432.

(4) Allameh, S.M., Lou, J., Buchheit, T. and Soboyejo, W.O., An Investigation of Fatigue in LIGA Ni MEMS Thin Films, Materials Science and Engineering, Vol.A371 (2004-4), pp.256-266.

(5) Yang, Y., Imasogie, B.I., Allameh, S.M., Boyce, B., Lian, K., Lou, J. and Soboyejo, W.O., Mechanisms of Fatigue in LIGA Ni MEMS Thin Films, Materials Science and Engineering, Vol.A444, Issues 1-2 (2007-1), pp.39-50.

(6) Haque, M.A. and A Saif, M.T., Mechanical Behavior of 30-50 nm Thick Aluminum Films under Uniaxial Tension, Scripta Materialia, Vol.47, Issue 12 (200212), pp.863-867.

(7) Haque, M.A. and Saif, M.T.A., Strain Gradient Effect in Nanoscale Thin Films, Acta Materialia, Vol.51, Issue 11 (2003-6), pp.3053-3061.

(8) Ogawa, H., Ishikawa, Y., and Kitahara, T., Measurement of Stress-Strain Diagram of Thin Films by a Developed Tensile Machine, Proceedings of SPIE's 1996 Symposium, "Microlithography and Metrology in Micromachining II," Vol.2880, (1996-9), pp.272-279.

(9) Ogawa, H., Suzuki, K., Kaneko, S., Nakano, Y. and Ishikawa, Y., Tensile Testing of Thin Films, Transactions of the Institute of Electrical Engineers of Japan, Vol.119-E, No.2 (1999-2), pp.73-79.

(10) Akiniwa, Y., Suzuki, T., Aoki, K., Kawai, M. and Tanaka, K., X-Ray Evaluation of Deformation Damage in Electrodeposited Copper Foil under Tensile and Fatigue Loading, Journal of the Society of Materials Science, Japan, Vol.55, No.7 (2006-7), pp.627-633.

(11) Rosenmayer, C.T., Brotzen, F.R. and Gale, R.J., Mechanical Testing of Thin Films, Material Research Society Symposium Proceedings, "Thin Films: Stresses and Mechanical Properties," Vol.130, eds. Bravman, J.C. Nix, W.D., Barnett, D.M., and Smith, D.A. (1989-5), pp.77-86, Materials Research Society.

(12) Merchant, H.D., Minor, M.G. and Liu, Y.L., Mechanical Fatigue of Thin Copper Foil, Journal of Electronic Materials, Vol.28, No.9 (1999-9), pp.9981007.

(13) Lee, H., Zhang, P. and Bravman, J.C., Tensile Failure by Grain Thinning in Micromachined Aluminum Thin Films, Journal of Applied Physics, Vol.93, No.3 (2003-2), pp.1443-1451.

(14) Simons, G., Weippert, Ch., Dual, J. and Villain, J., Size Effects in Tensile Testing of Thin Cold Rolled and Annealed $\mathrm{Cu}$ Foils, Materials Science and Engineering, Vol.A416, Issues 1-2 (2006-1), pp.290299.

(15) Arai, M. and Ogata, T., Development of Small Fatigue Testing Machine for Film Materials, Transactions of the Japan Society of Mechanical Engineers, Vol.68, No.669-A (2002-5), pp.801-806. 
(16) Miura, H., Materials and Mechanics in Nano Scale, Transactions of the Japan Society of Mechanical Engineers, Vol.72, No.717-A (2006-5), pp.595-601.

(17) Fukushi, M., Miyata, H. and Murakami, A., Development on the Tensile Fatigue Test Apparatus and Strength Evaluation of Thin Metal Films, Transactions of the Japan Society of Mechanical Engineers, Vol.72, No.718-A (2006-6), pp.880-885.

(18) Sharpe, W.N., Jr., Yuan, B., Vaidyanathan, R. and Edwards, R.L., New Test Structures and Techniques for Measurement of Mechanical Properties of MEMS Materials, Proceedings of SPIE's 1996 Symposium, "Microlithography and Metrology in Micromachining II," Vol.2880, (1996-9), pp.78-91.

(19) Mehregany, M., Howe, R.T. and Senturia, S.D., Novel Microstructures for the in site Measurement of Mechanical Properties, Journal of Applied Physics, Vol.62, No.9 (1987-11), pp.3579-3584.
(20) Tada, N., Shimizu, I., Kanamura, K. and Tada, H., Tensile Test of Thin Titanium Plate Actuated by Thermal Expansion of Polycarbonate, Proceedings of the Sixth International Congress on Thermal Stresses, eds. Ziegler, F., Heuer, R. and Adam, C., Vienna University of Technology, Austria, Vol.2 (2005-5), pp.593-596.

(21) Fujita, H., Introduction to Micro/Nanomachine Technology (in Japanese) (2003-8), pp.183-224, Kogyo Chosakai Publishing Inc.

(22) The Nilaco Corporation, Materials Catalog for $R \& D$, No.29 (2004-7), p.226.

(23) Takiron Co., Ltd., Polycarbonate Plate Technical Datasheet (in Japanese) (1998-12), p.3, p.11.

(24) Nishikawa, I., Digital Correlation Method for Full Field Displacement Measurement, Journal of the Japanese Society for Non-Destructive Inspection, Vol.54 (2005-3), pp.132-138. 